Bridge.

Sowthern Marianas II.

$$
6 / 9
$$

\title{
WMITED STATES
}

\section{DEPAFTWENT CE THE INTHRIOR}

\section{DI-6}

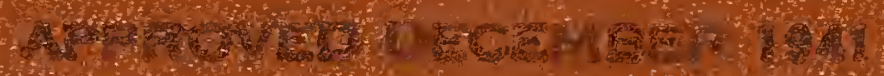




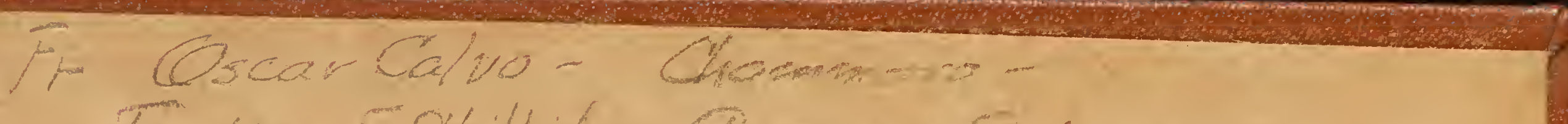

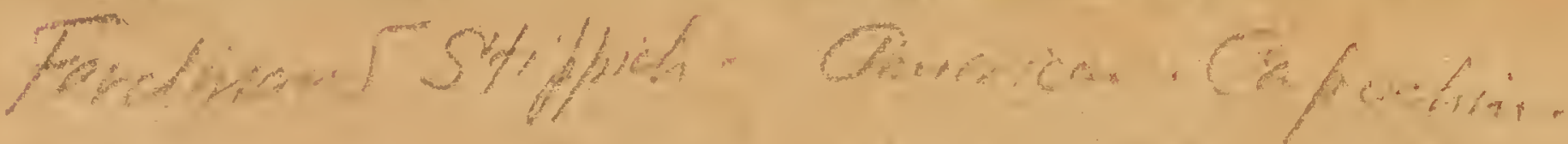




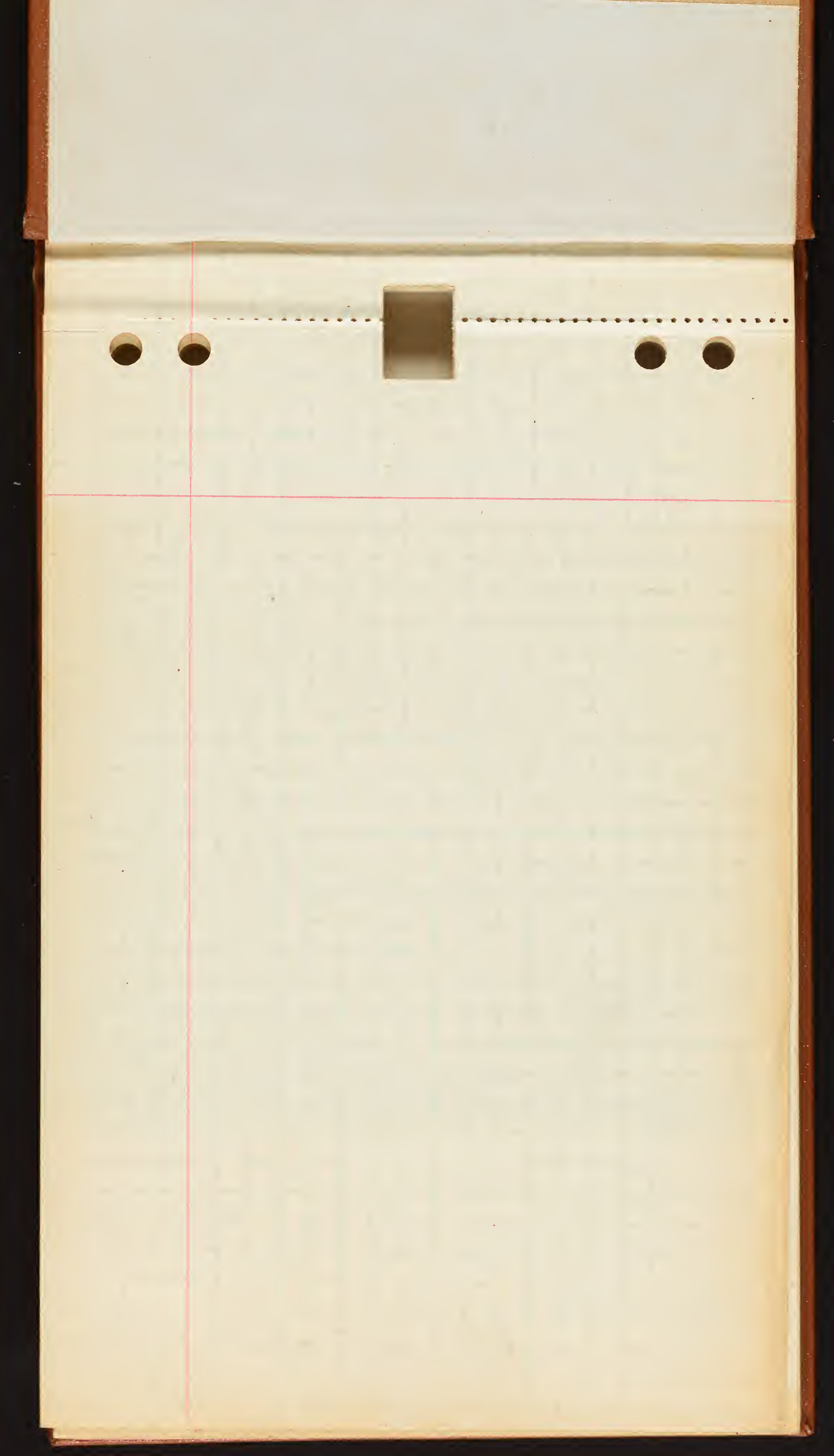




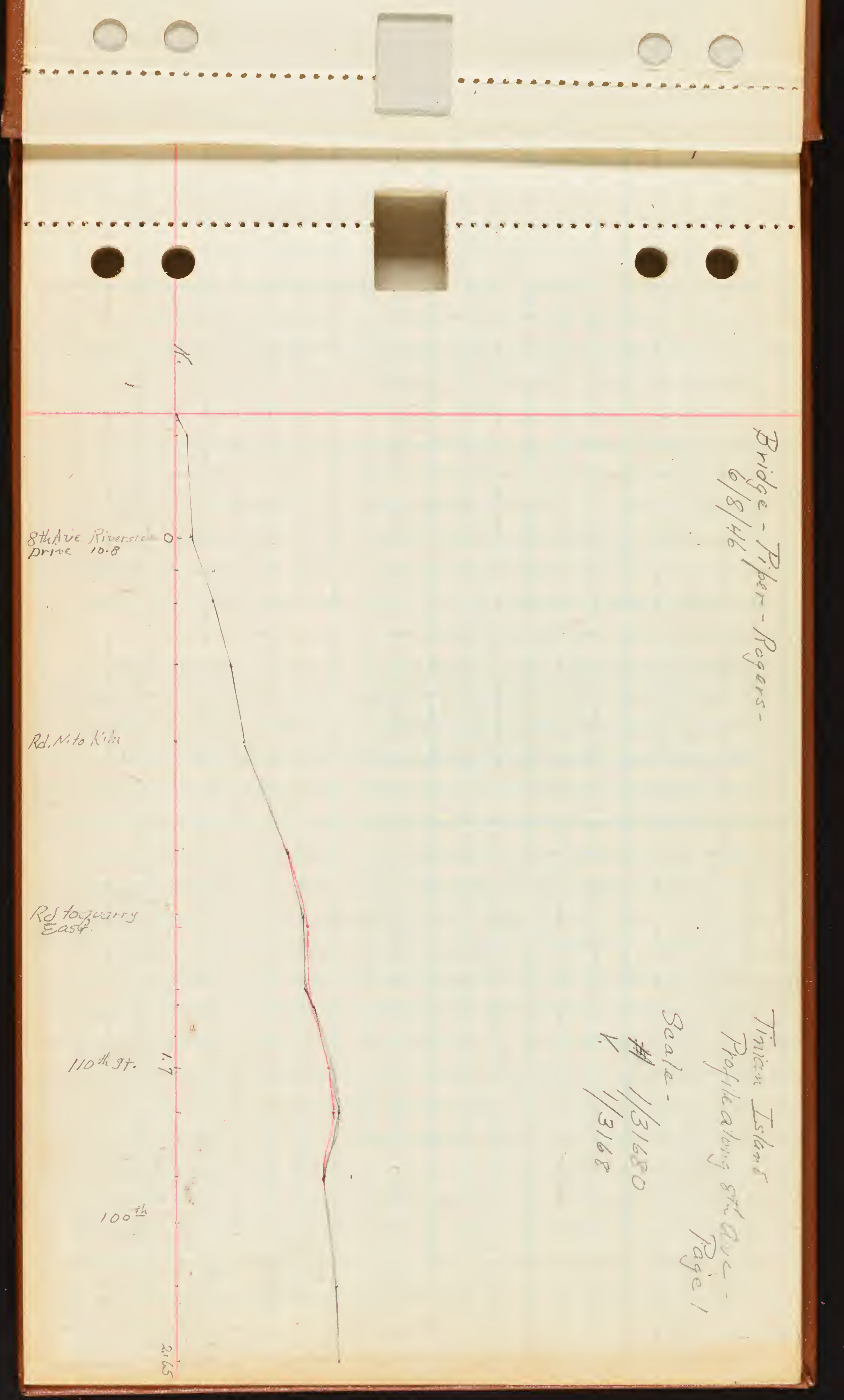




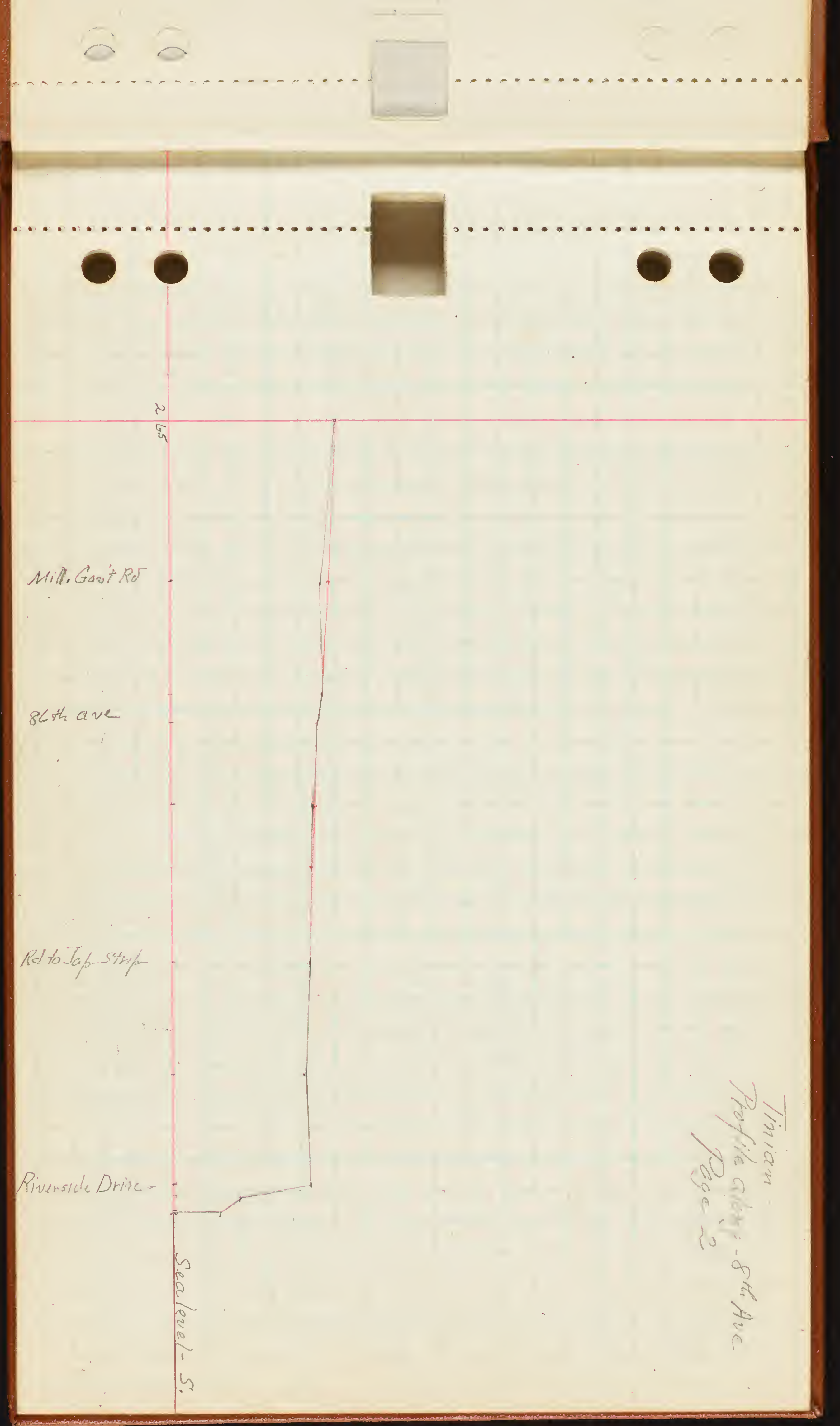




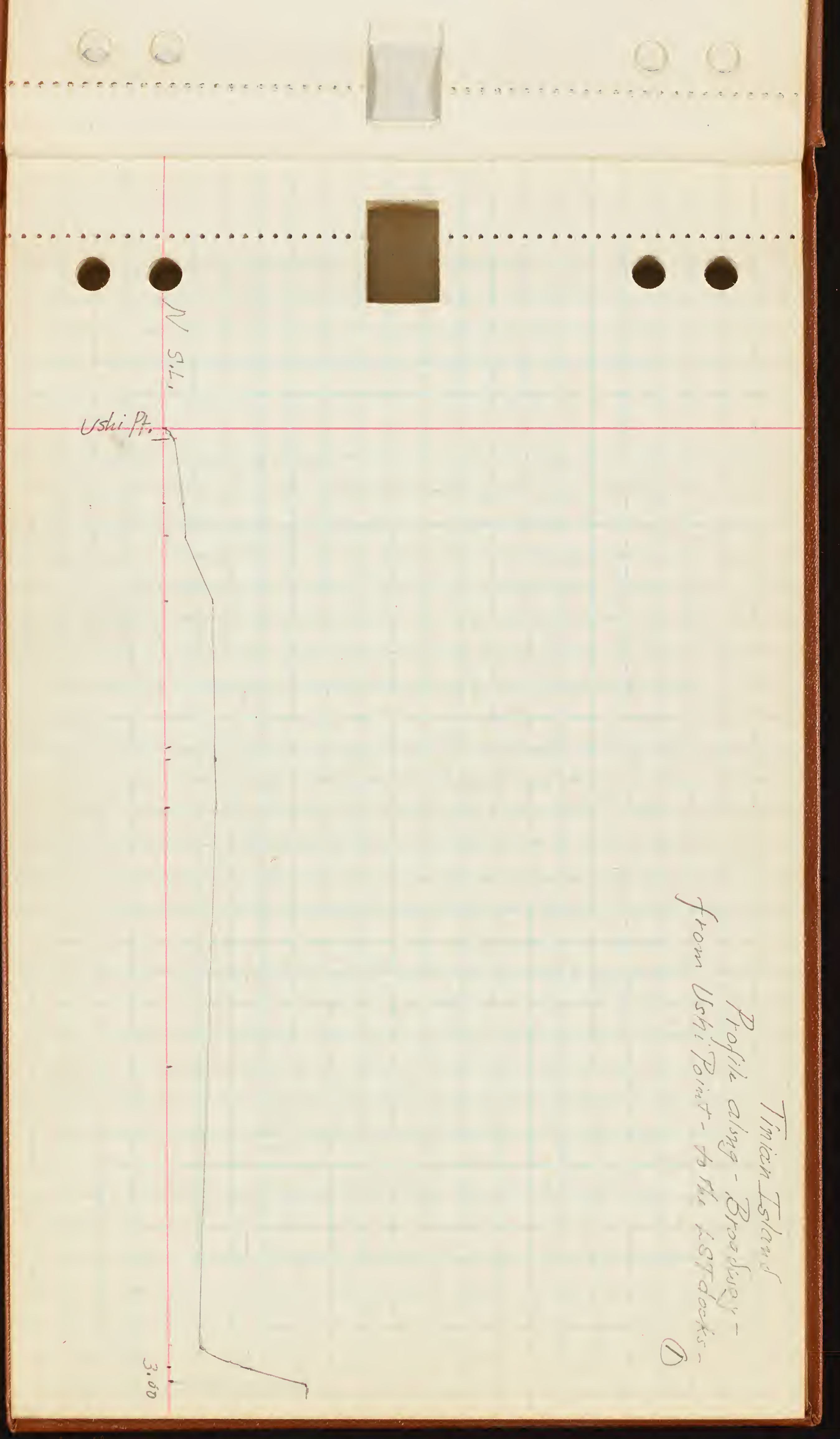




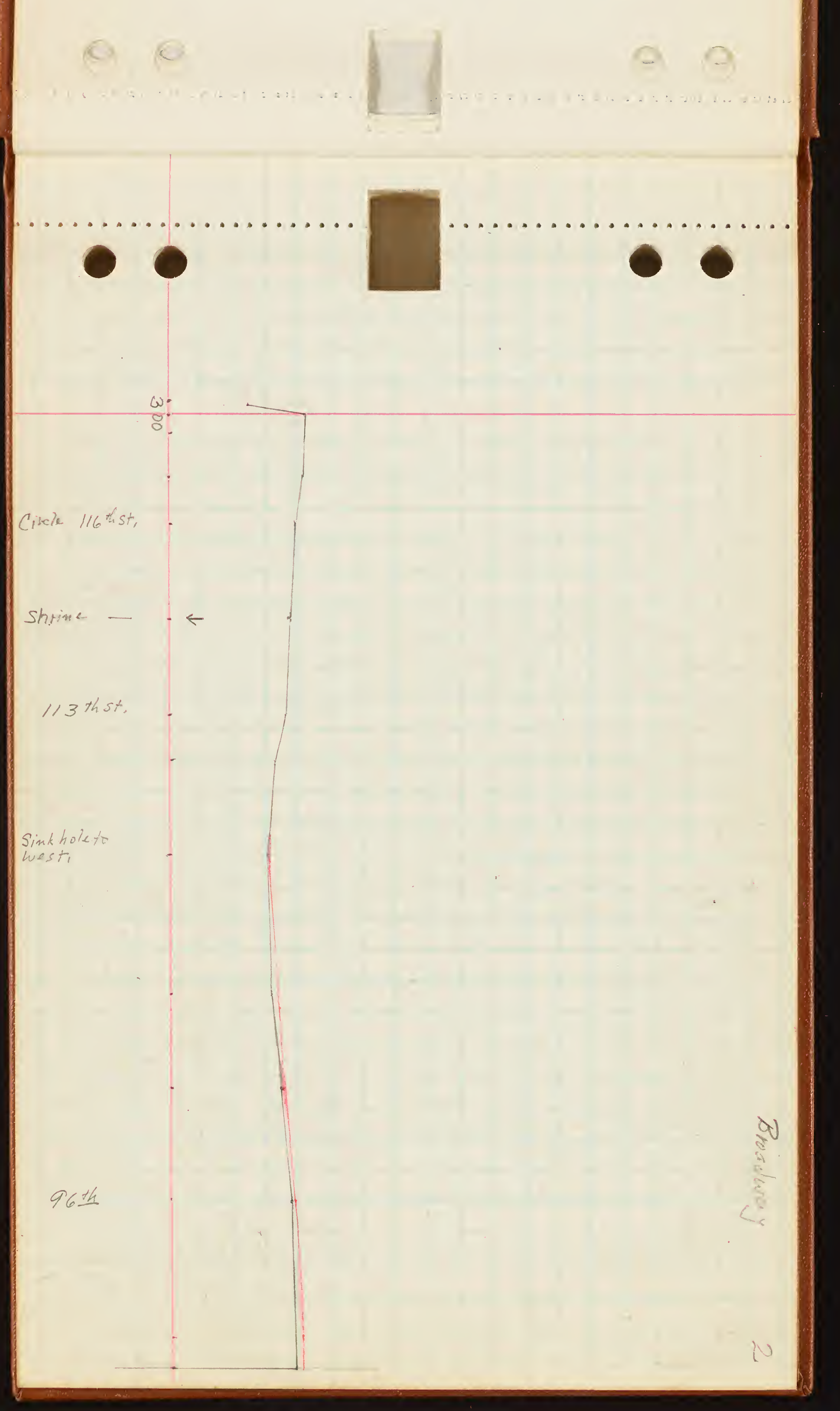




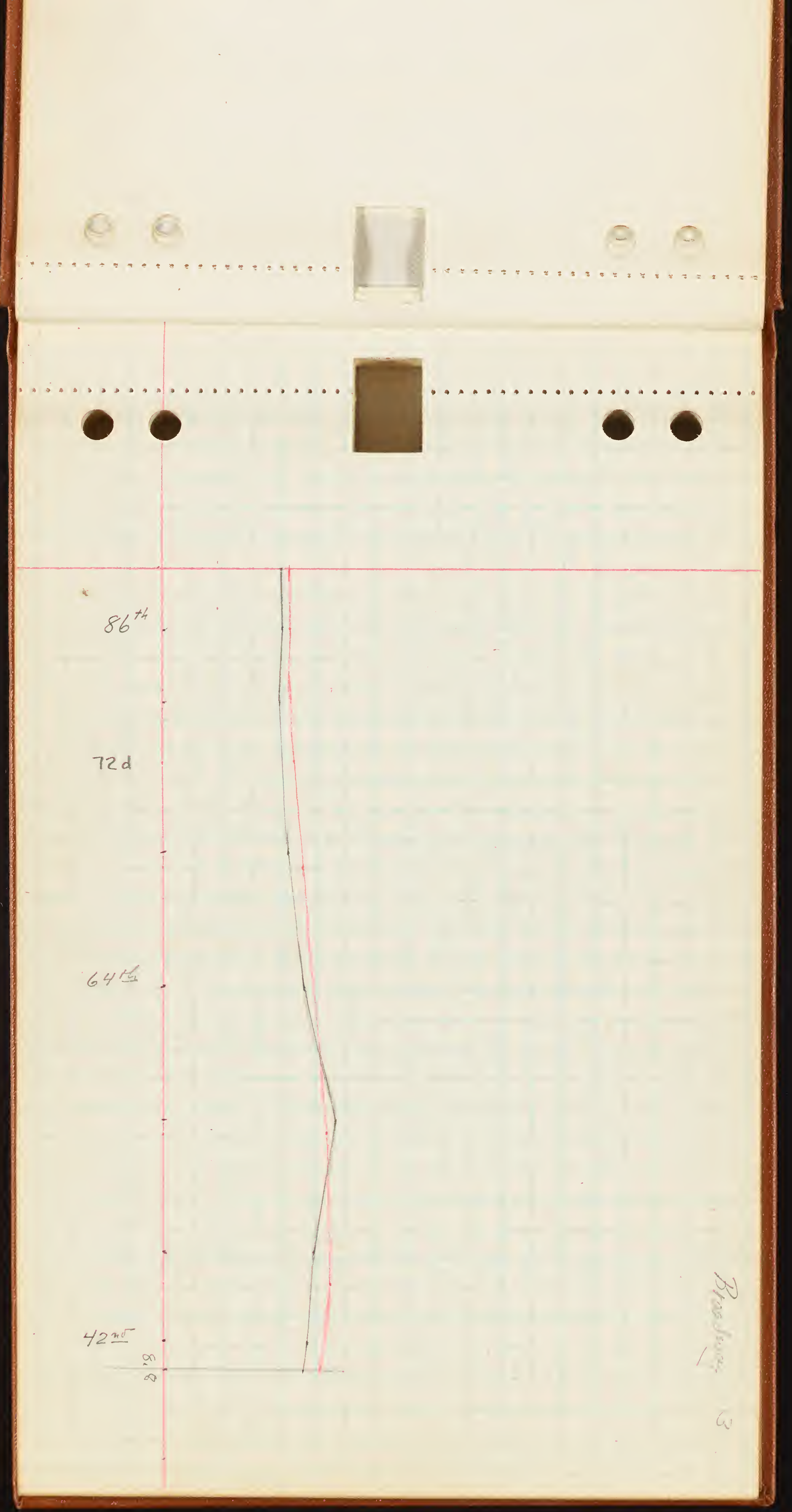





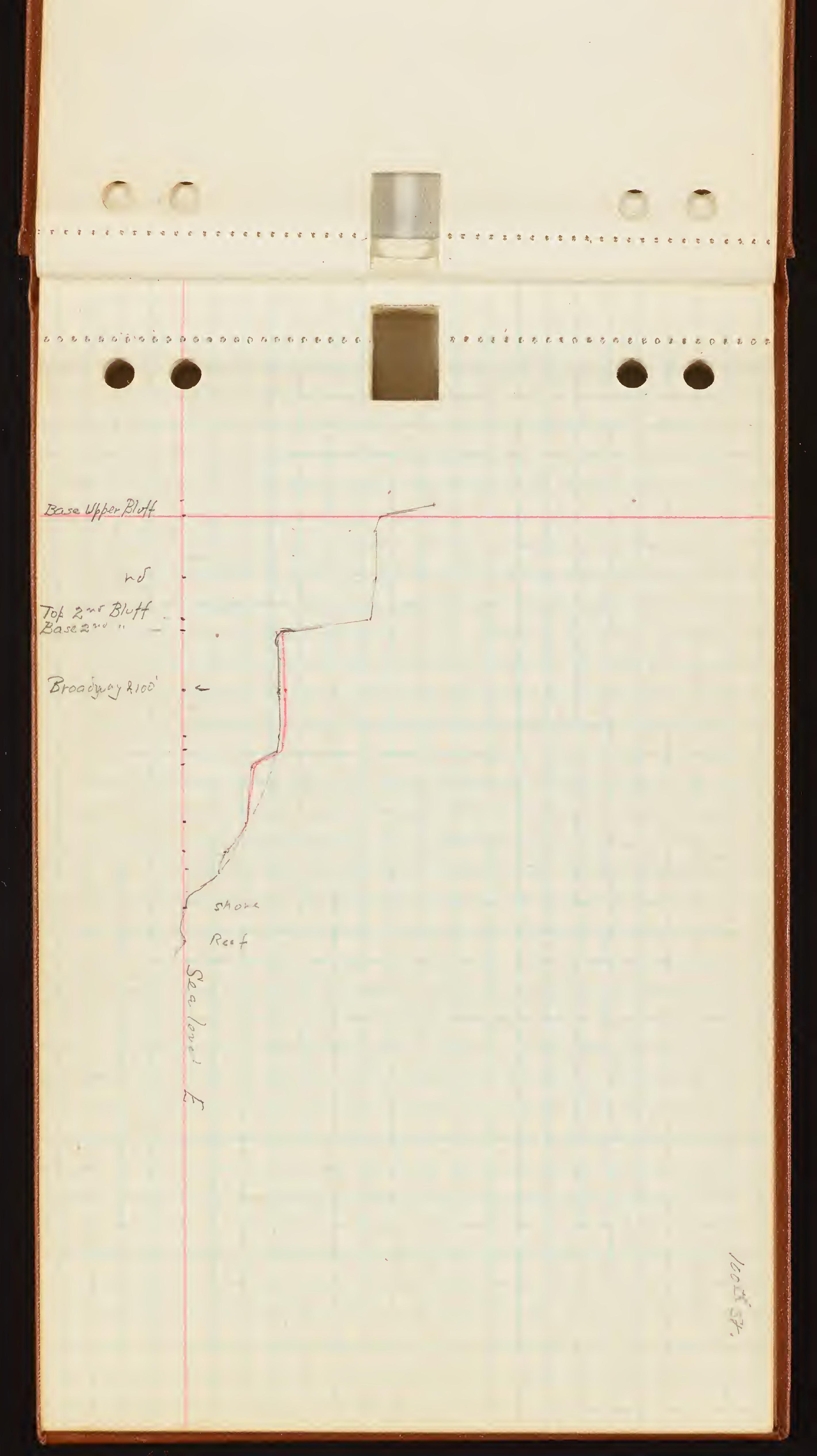




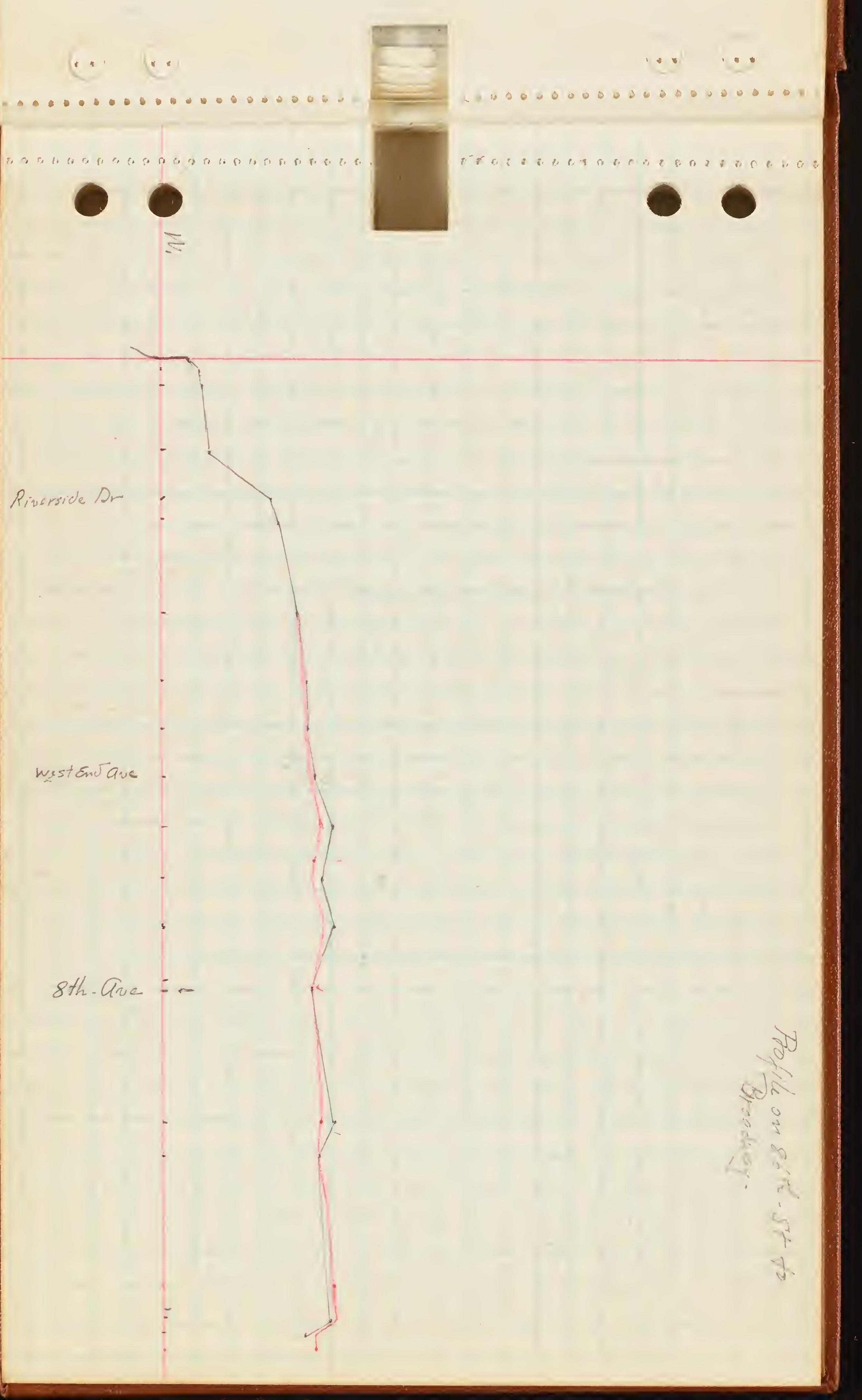




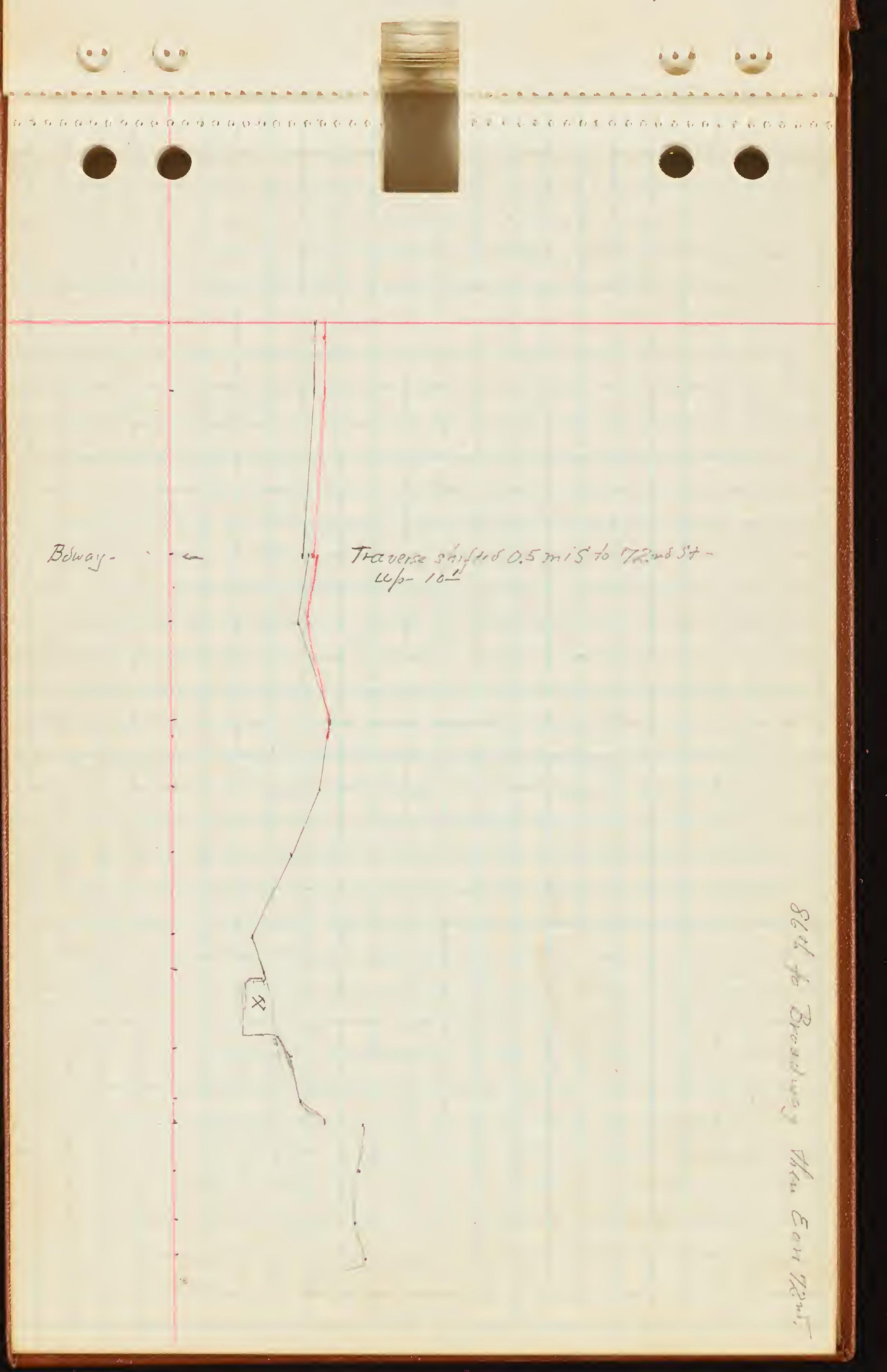




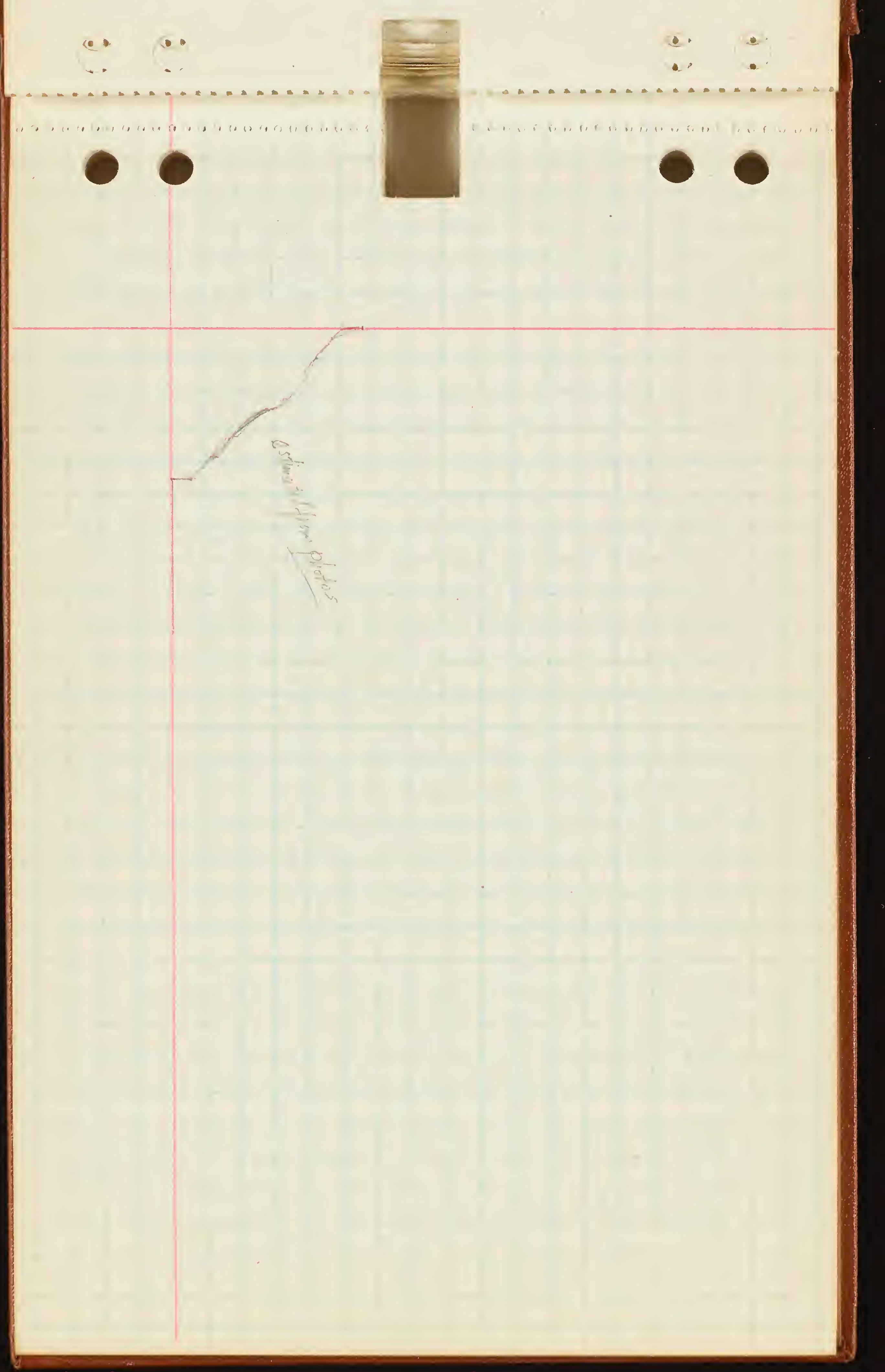





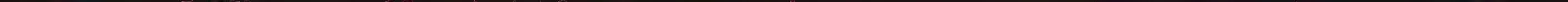




\section{-}
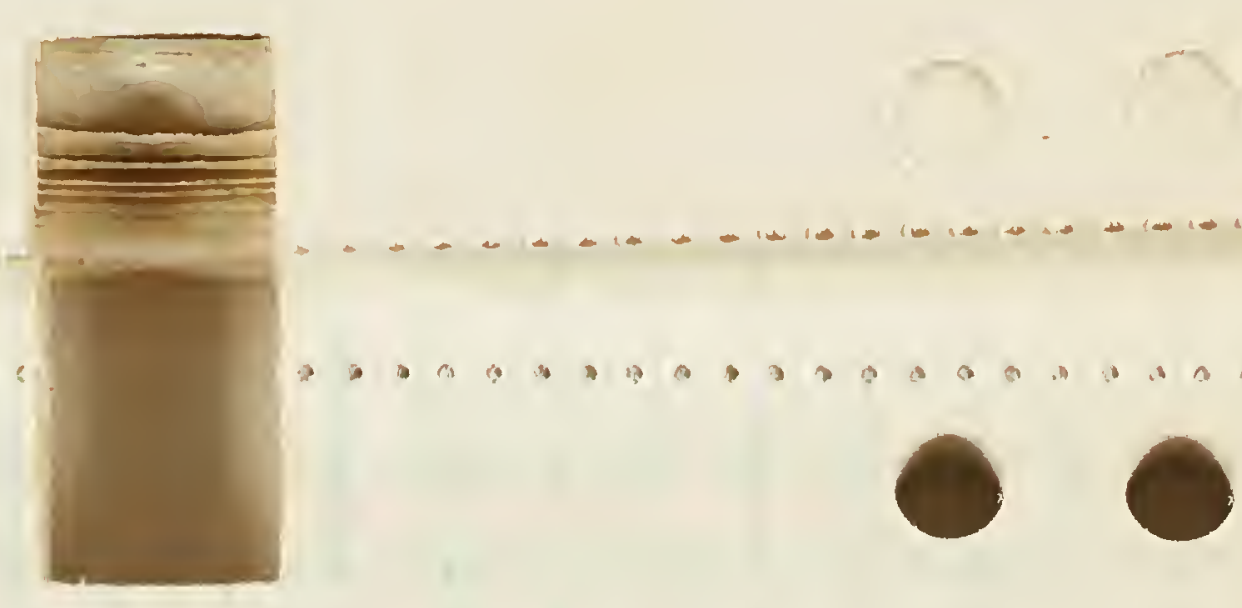

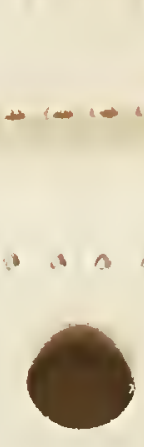

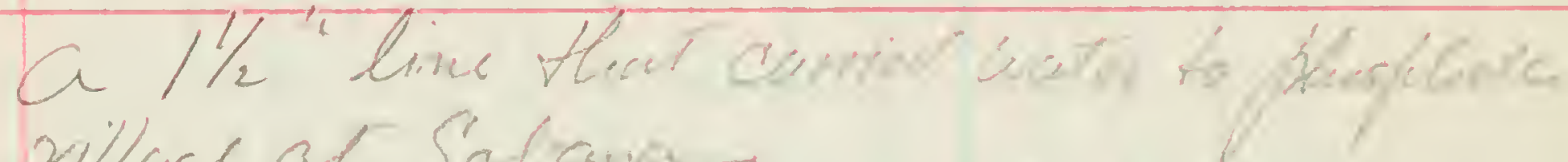
village at Sabana

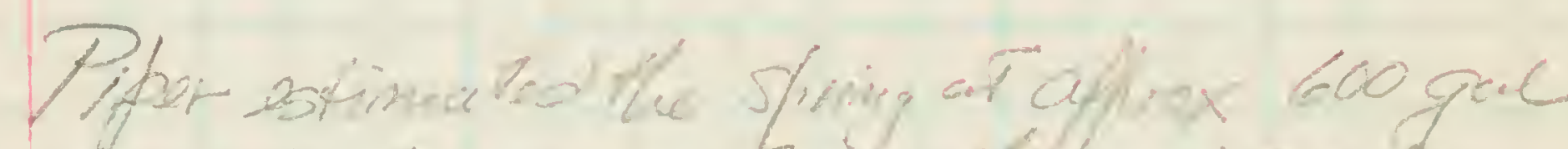
perminute - mare thith inew fo. 


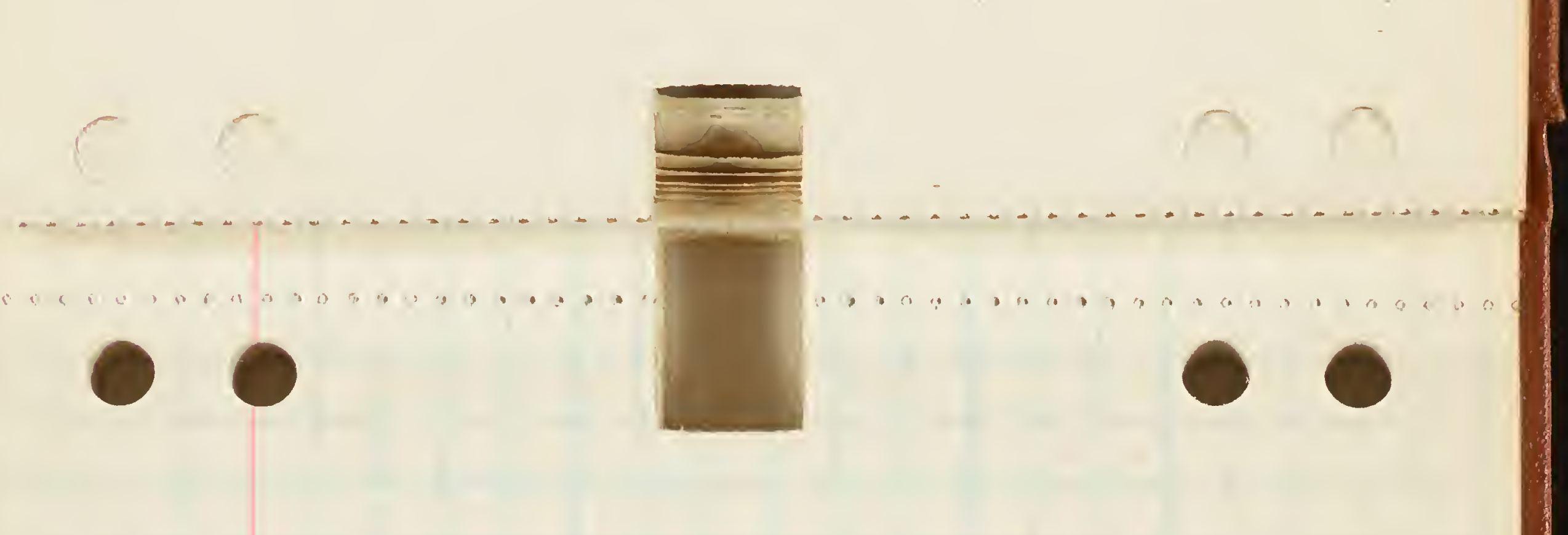




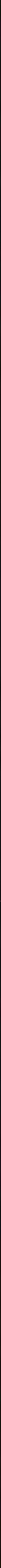




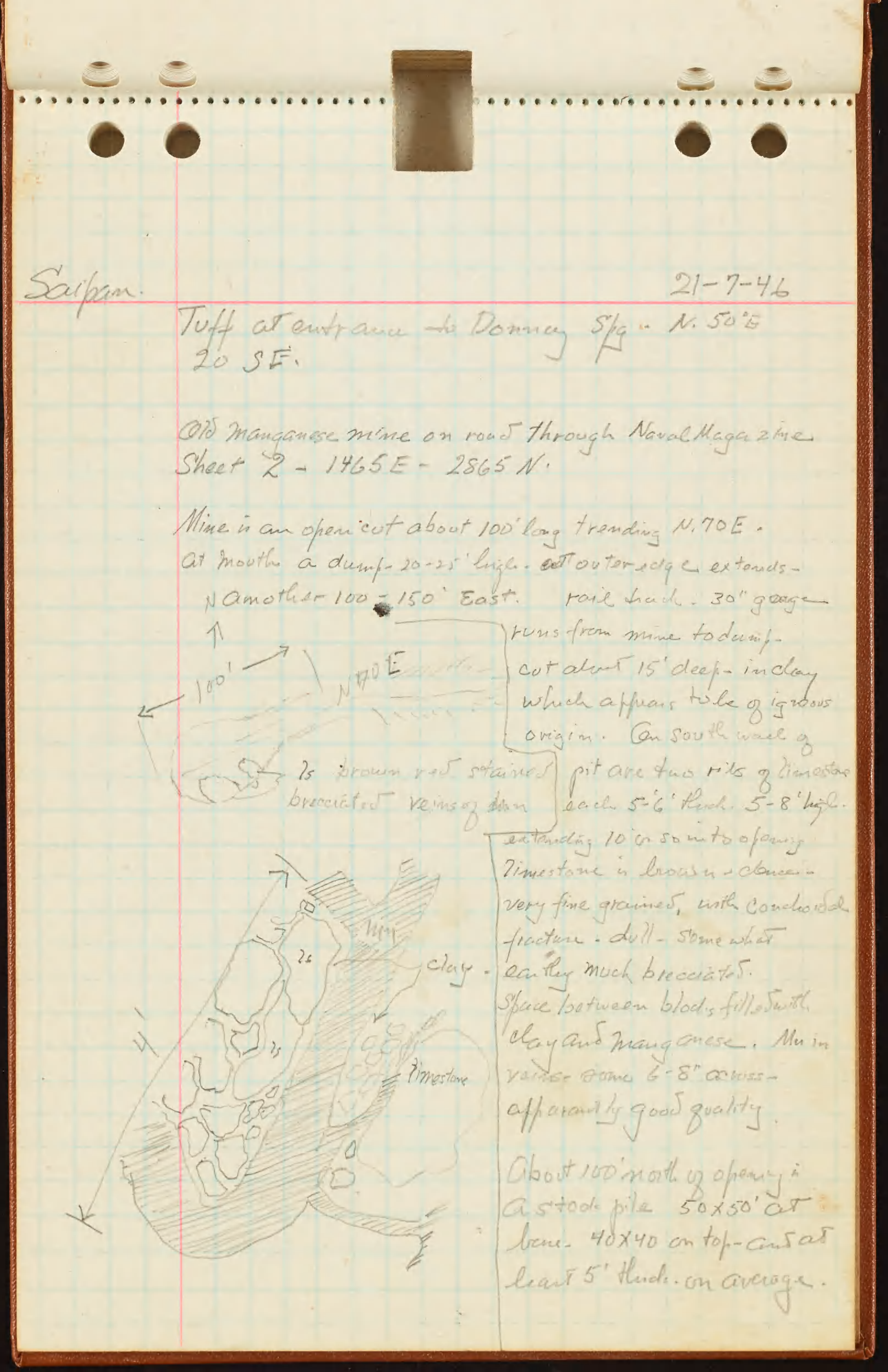


$\because \quad$ T 


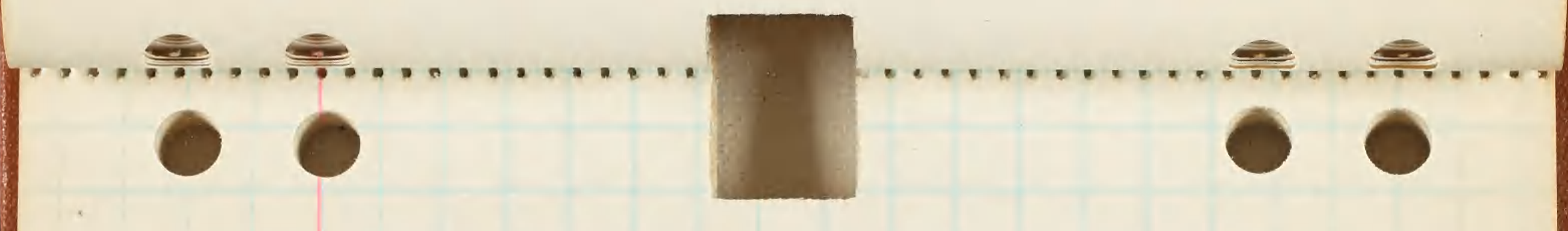

Saipan Collections

3-16 Limestone. Ridge along hillside north fanet north of Mt. Atchugar - Sheet 2 $1340 E-2905 N$ - East side o Valley
Photo 16 Elew abt. $160^{\prime}$

S-17 Limestone a fewfeet dam hill (west) of Precueding- Sheet $21240 E-2905$ of
Photo /6.

S-18 Rorlimestone. Small quarry on old Road to KarraberraPass - Elev a abt 300 shoet 2 1395 E-2965N- Photo 16

S-19 White limestone same locality as S-18

S-20 Decomposed Andesite- old road to karrabaraposs - at sharp torn - Elev- 120 Sheet 2,1361 E-2958 N- Photo 16

S-21 Bedded, mediumarained tutf. Sheet's along roar Charan-Kanoa to kobsley field on steep grade $0.4 \mathrm{me}$ Nhotoll, Robler. Sheet s-0565E-1598 N

S- 22 Coarse graimer bedder, tuffaceous agglomevate Just eart of S-21-Sheet's.0572 E-1601 N Photoll 
Saipan Collections,

S-23 Soil- near officers mess, Casual co north on Galaperi- Sheet 2 1570E-2835NO Photal/6

S-24 Limestone with micrafossils resting on thyolite Due easto MrCCtch gau - in benio gor cane. rowe. Sheet 2 1395E-2867NPhoto 16

S-25 Limestone with miora fossils (lange) $3 r i \mathrm{Cu}$ from west on oes tailroad grade above LavlauBay- Sheet 3 - 1040 E-1965 N-

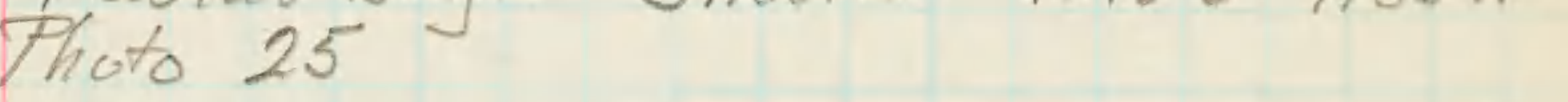

S-26 timestone Int Ciutfrom west old rrgrade above Laulau Bay. Sheet 3\% $1022 \varepsilon-1961$ N . Photo 25

S-27 Andesite $5^{\text {th }}$ cot from west on of r rrarade Above Lavlau Bay - Sheet 31076 E- $4980 \mathrm{~N}$
Photo -25

S-28 Tuff-Donnay - 2urd cut on East side Hy No Junction with Western Base Ro. Sheet 4 1/282E-2505 N- Photo 15, 16 28 -a fine grainer 28 - $b$ coarse graimer over 


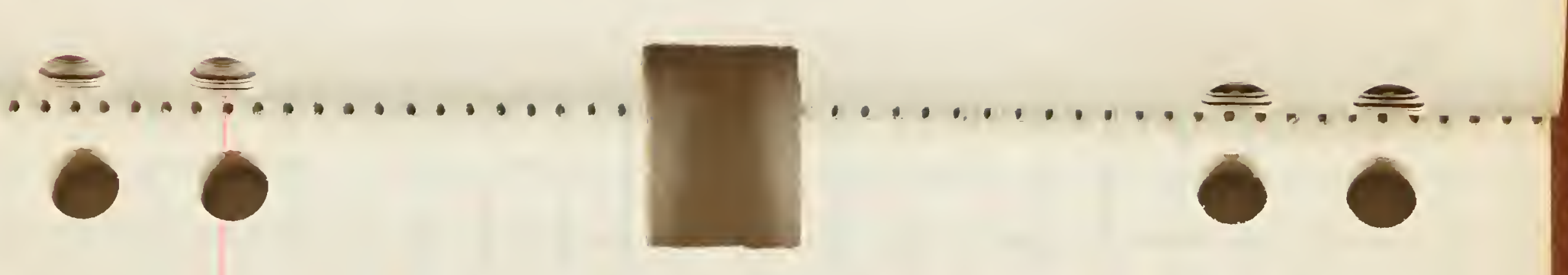

Yying $28-a$

S-29 Limestone at Ananganese minc east on Mt Atachugail Sheer' 1463 E-2867N Photo 16

S-29a Nangawose fiom wius in s-29-

S-30 Fossilfferousls - Samalic ao $s-z$ Sheet 1 $-1030 \mathrm{~L}=-2760 \mathrm{~N}$ - Phete it

S-31 Fossiliferous is - near fautt on roou to Radio Whill-Sheet 2 - 1188tE $2840 \mathrm{~N}$. "Phot lo

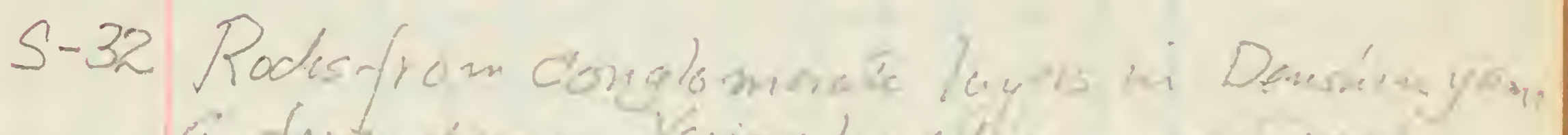

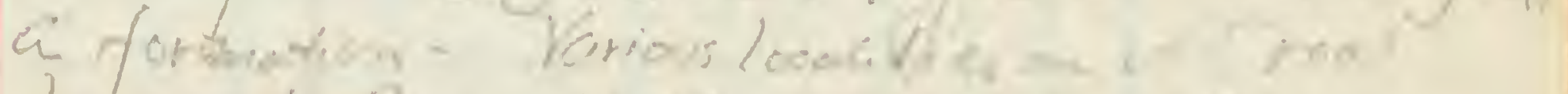

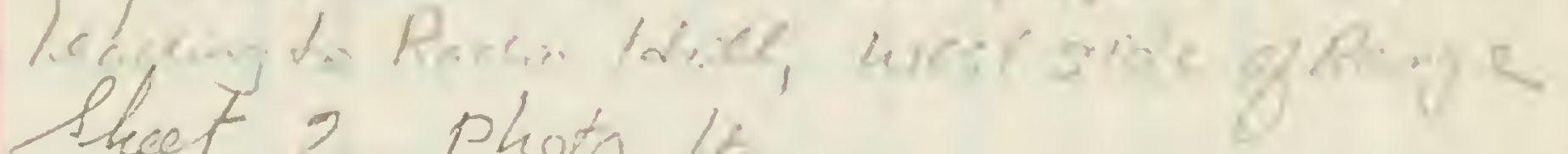
Sheet 2 photo it

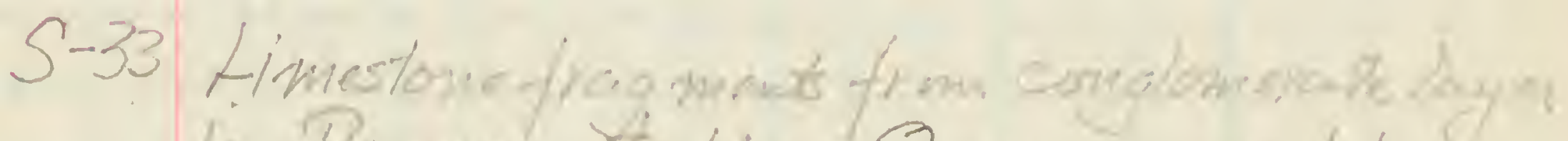
In Demnay vuft. Quary on raad to Fuloug Fieds- Sheet $3-2830 E-1730 \mathrm{~N}$
Photo 16 



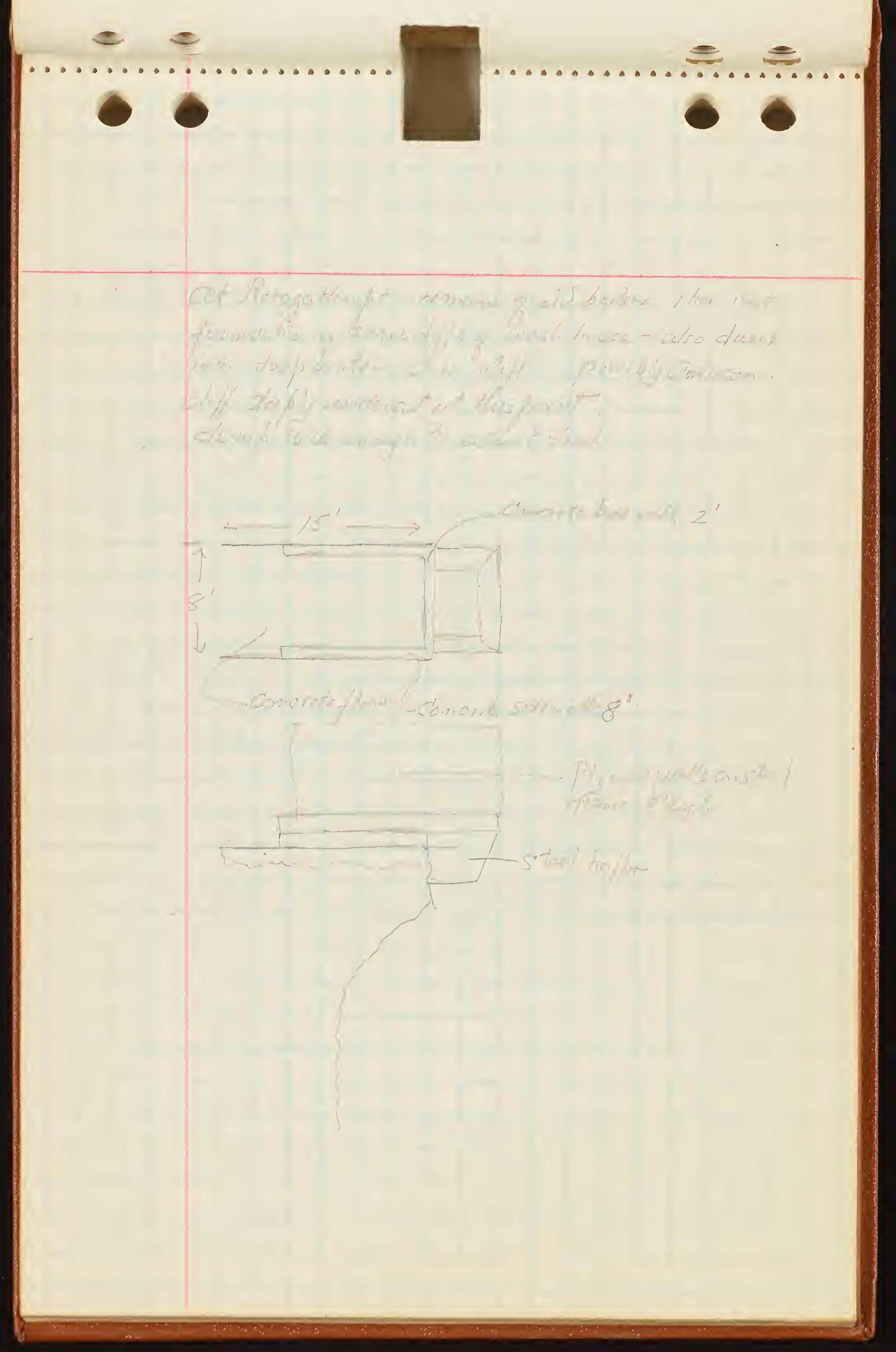




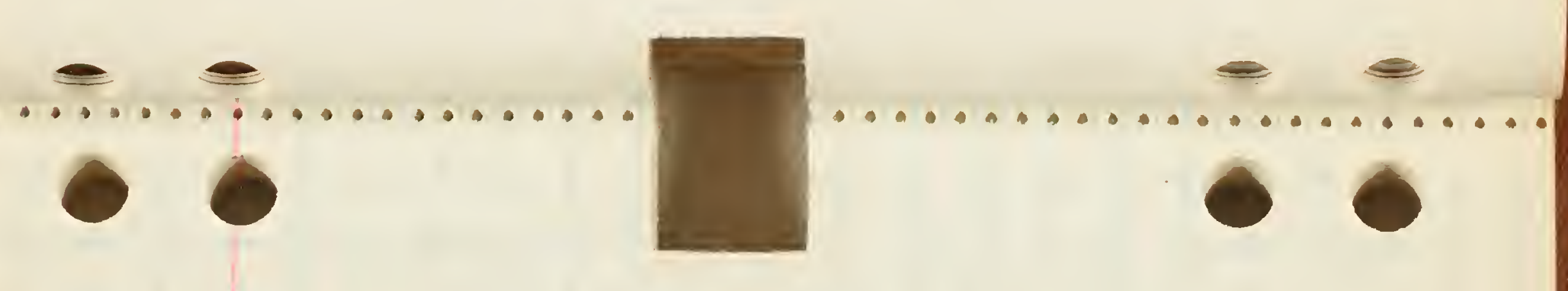

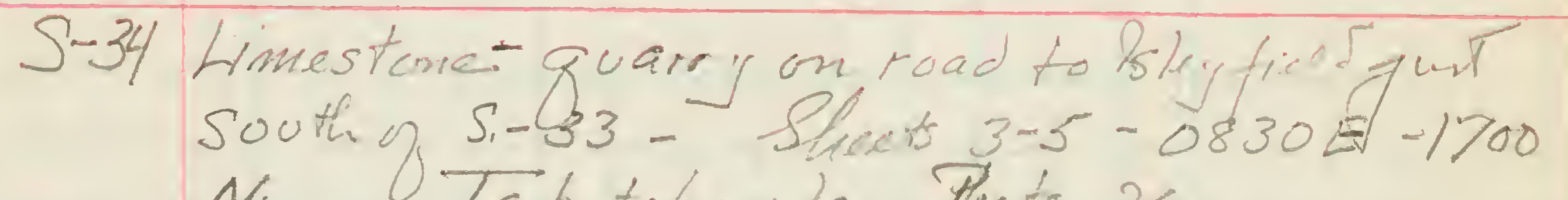
Ni Tapotchouls. Theto 26

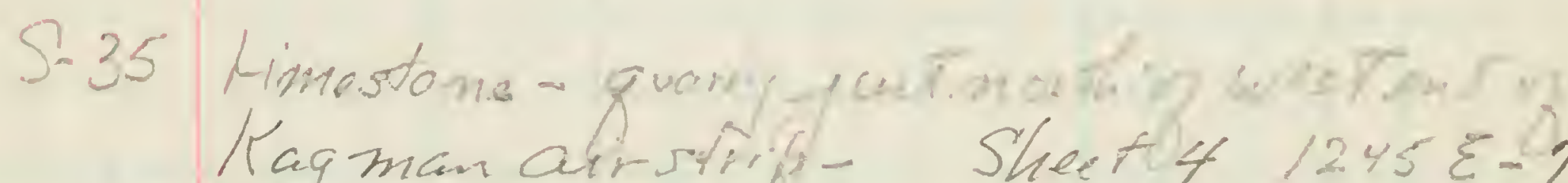
Kagman ahrstiple- Sheet 41245 E-2010N.
Photo 25.

S.36 Breacia ferim Donnay tuff. Raymm Torit neancrestat SE tip. Manglamese cirs Sheerty - 1460E- Y860\%-Photo 25

S-37 Limestone. Porogattan Pt atedye of clift dow 60 'abure sea Mariana is? Sharty 1580 E- $2018 \mathrm{~N}$ - Ste Photo 25 


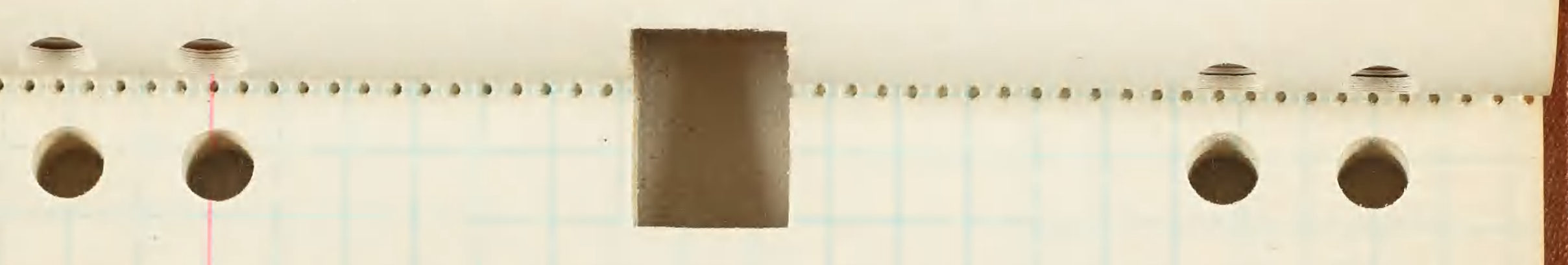

Kagman Point. Shoot 4 .

The point rises steeply above flat to west, and a plears to be an up faulter block. If is composes primarily of tuffDomnay.ans possibly some of the Denshinyama beds on the west ride. Al though Tay a man mafs andesite here ano names the Haymon andesite from this aree, If faicer to finitany exposores which couls unquestionably be reforecor to that formation, In ascendive, the steeptinec on the western face found leds of coarse ans fine conglomerate, the palles primarily of inoous origin-

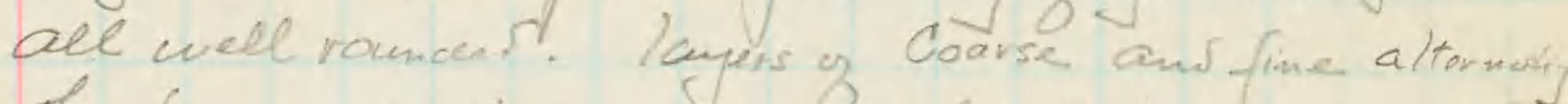

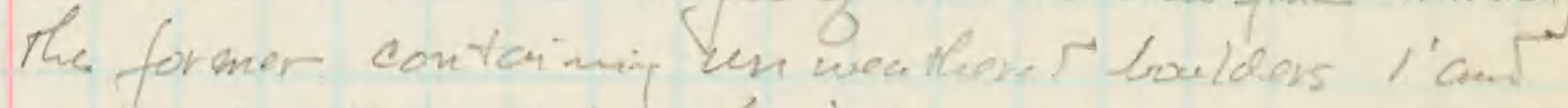
mobe in diame ter $=$ - the latter completely weationer. pepblescand alle and the whole spotion resembling the Section of the Denshingrama hests seen atong the roas on the west srida of Padio till.

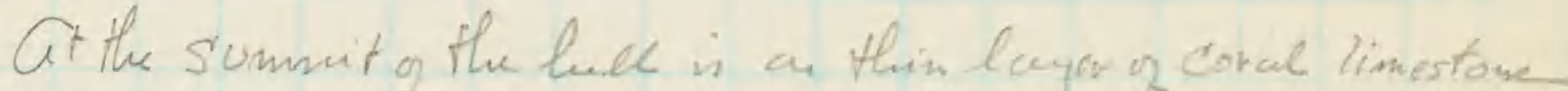

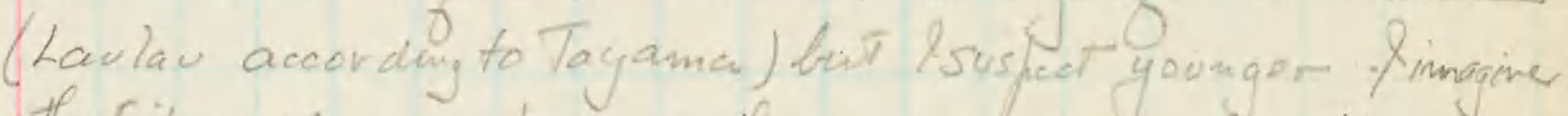
that it will prove to the of the same age tas the limesterm under Kayman fied. Thioledye cofis the south fan.

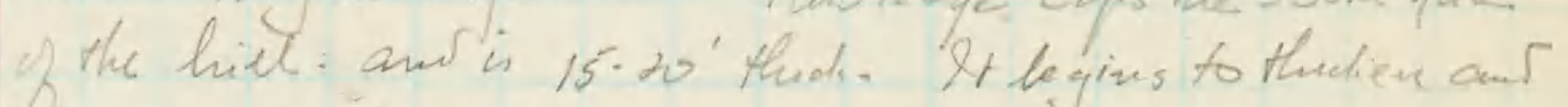
plouge on the eastom sider - Caffer the Cong sfor at 1500 te $1940 \mathrm{~N}$. Anerfinady readen this sea just north of the thirs point on the east coodt. cousuriug from thes south. $1520 \varepsilon-1938 \mathrm{~N}$.

The white eastface below this limestone i made of of the Donnay toff - Mostly fine grain F yellowit? 


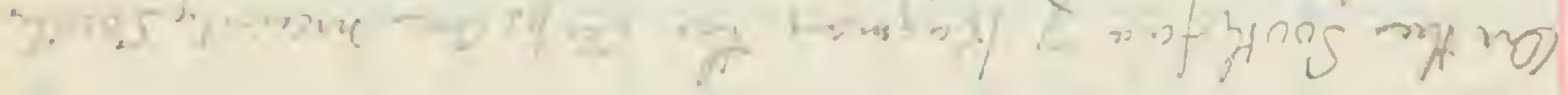

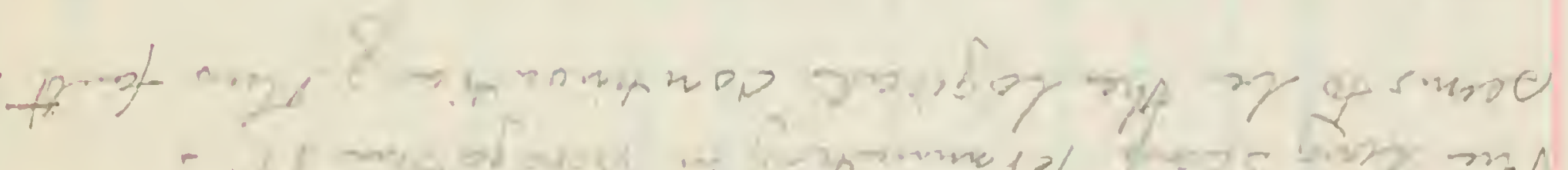

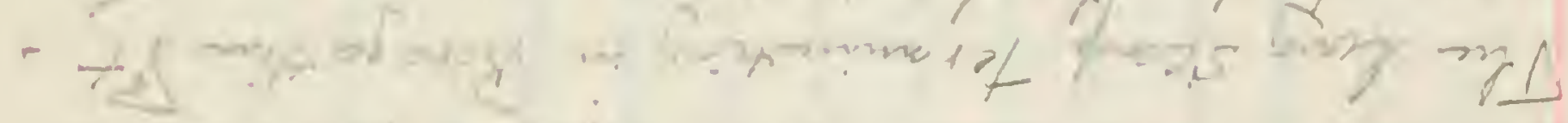

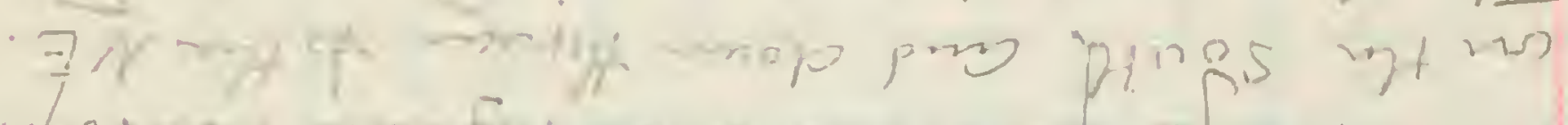

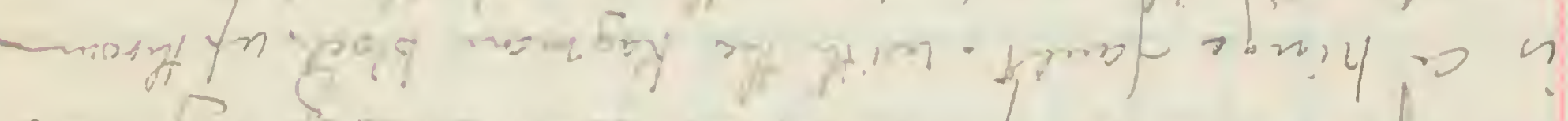

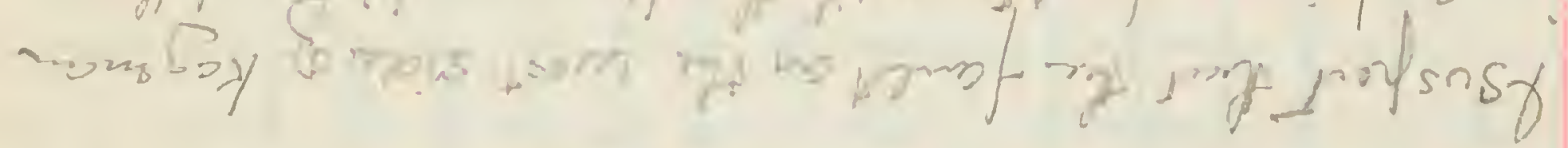

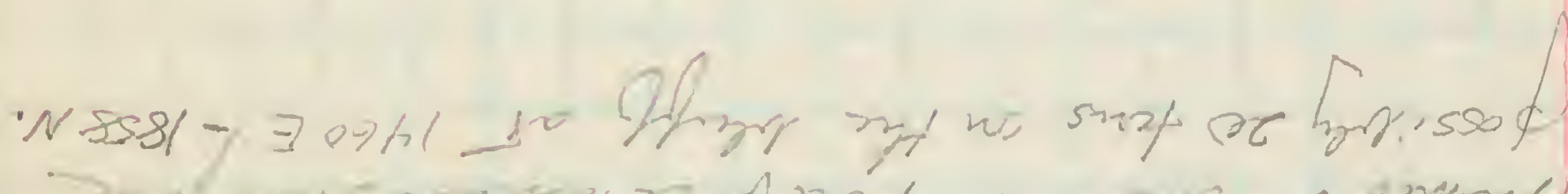
P LA.

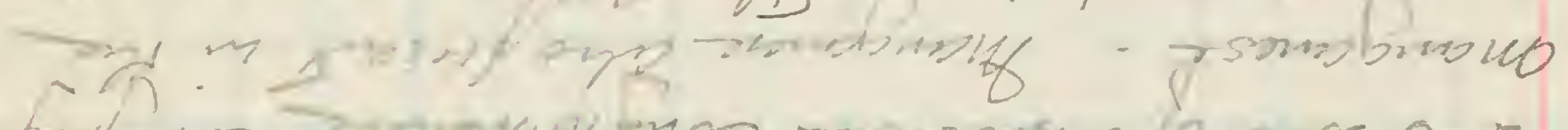

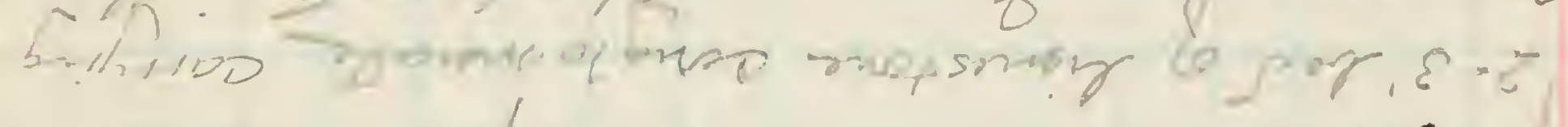

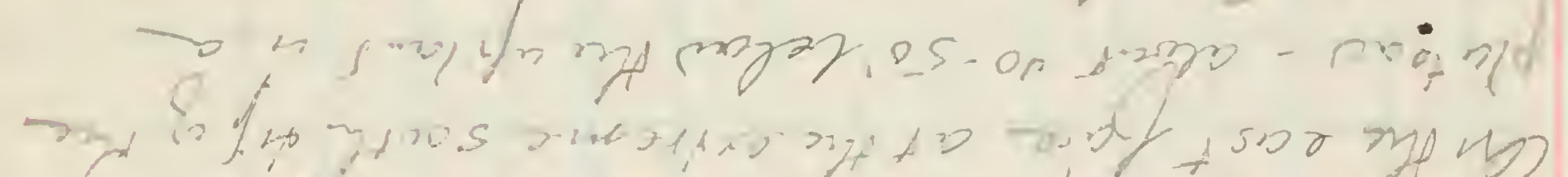
年,

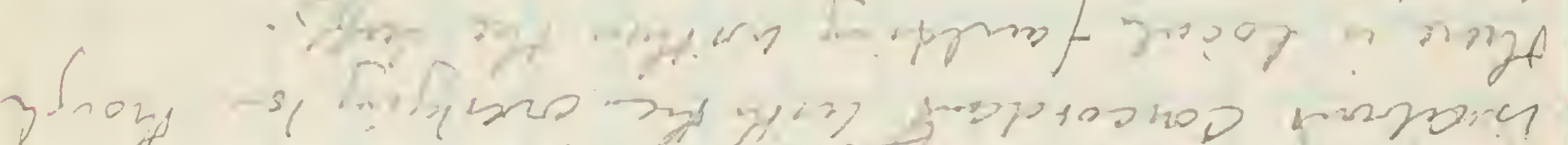

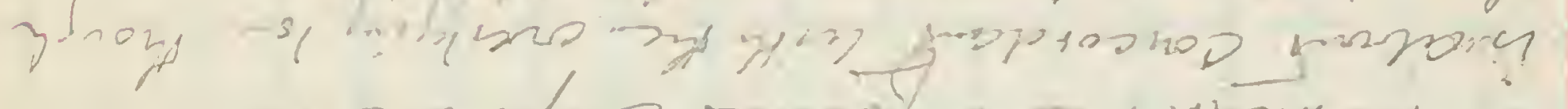

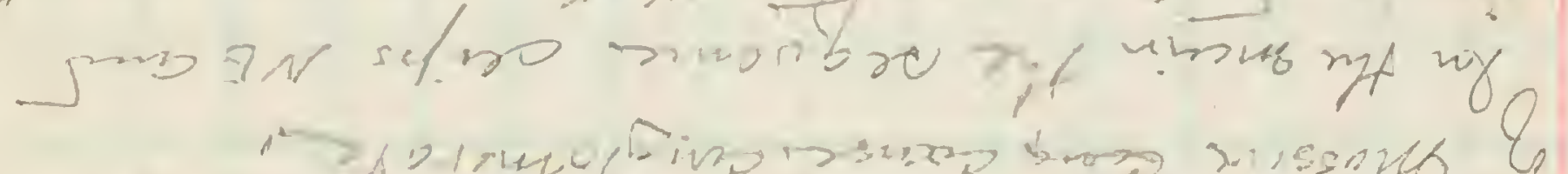

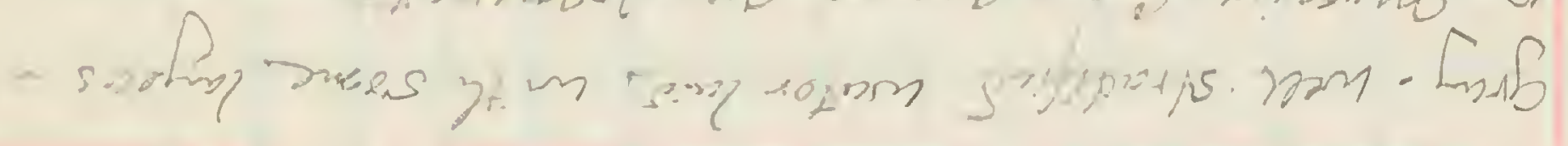




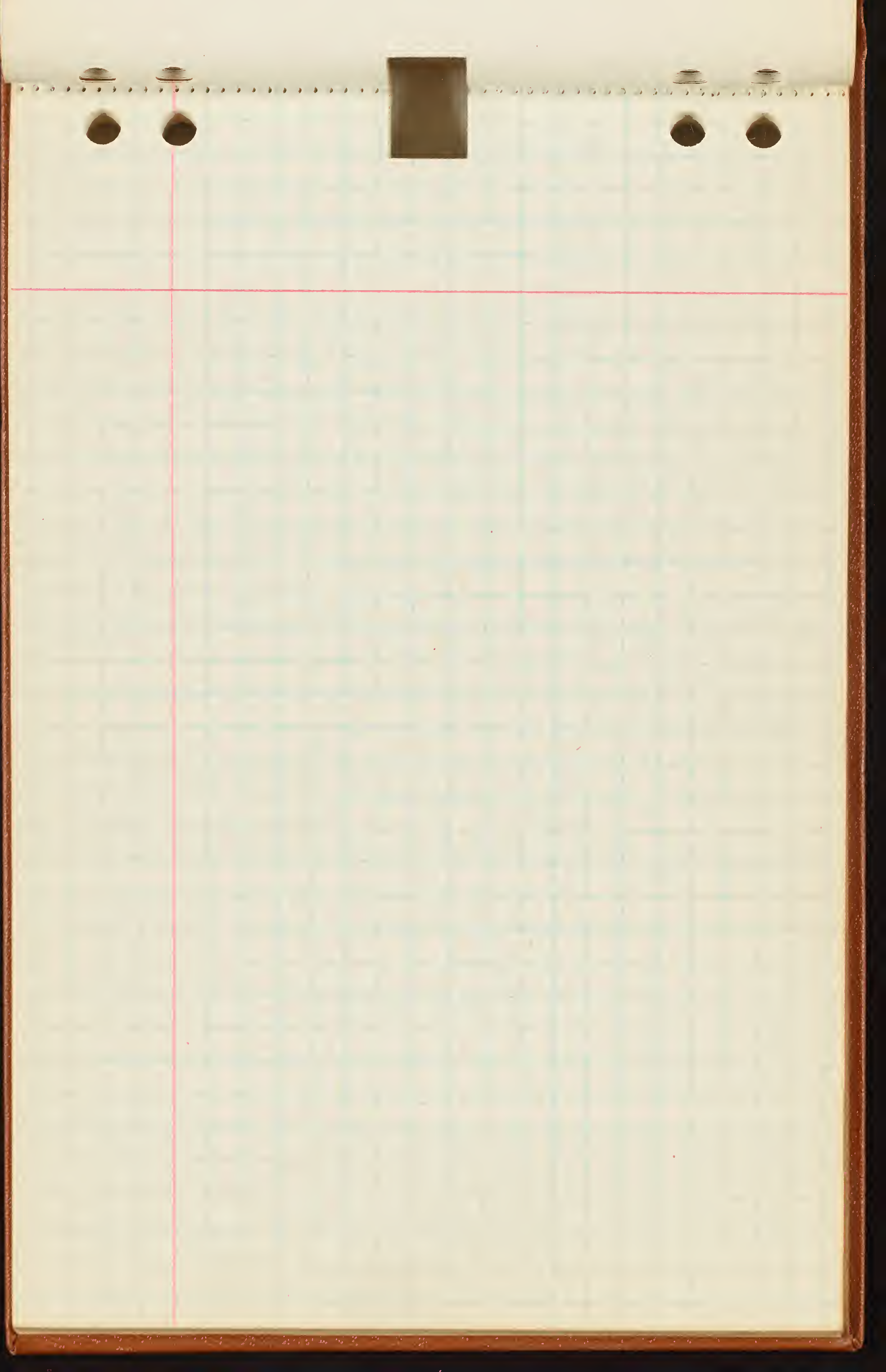






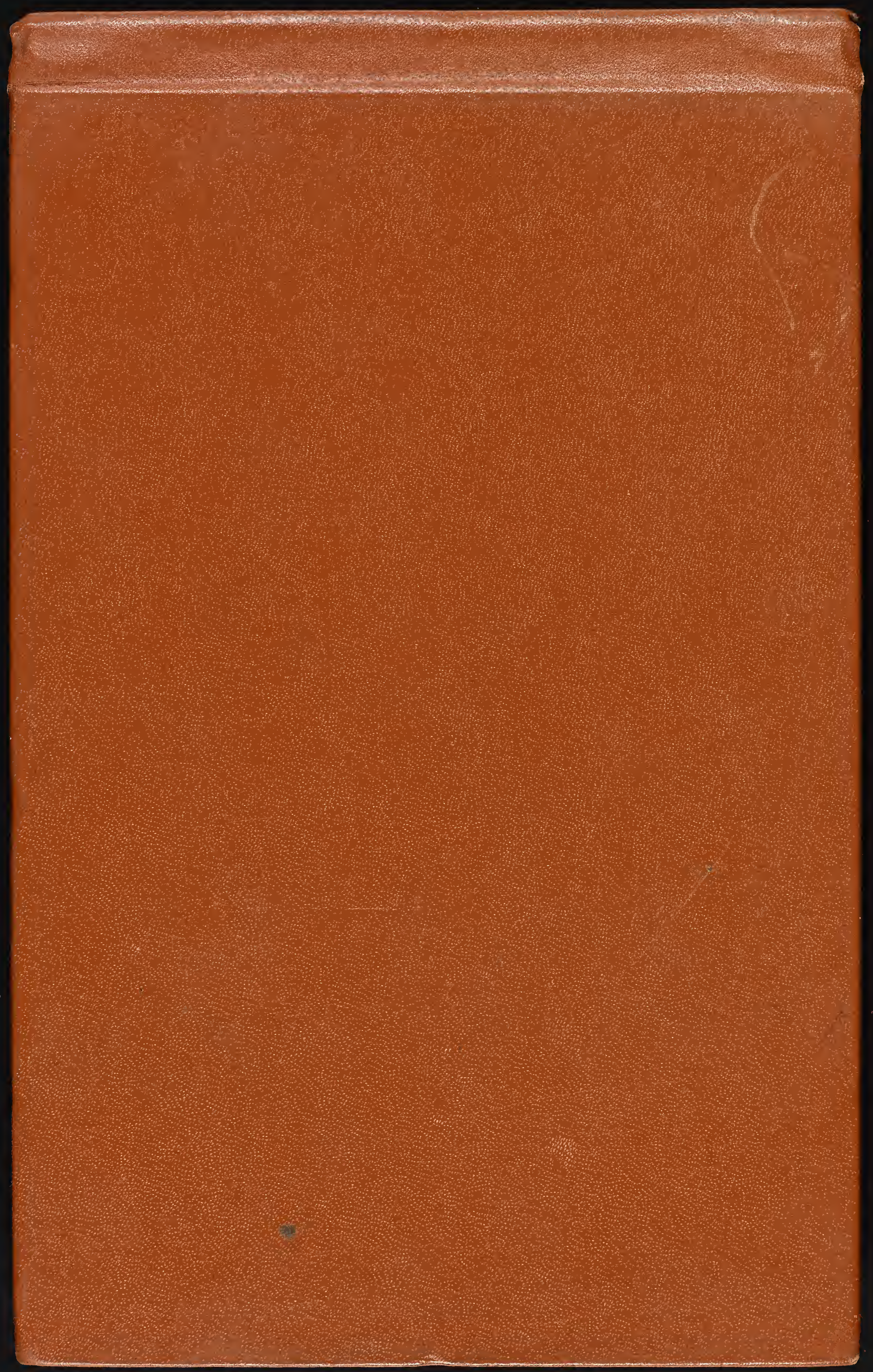

